\title{
Energy efficiency in the agricultural and food industry illustrated with the example of the feed production plant
}

\author{
Jacek Gembicki1,a \\ ${ }^{1}$ Szkoła Główna Gospodarstwa Wiejskiego w Warszawie Wydział Inżynierii Produkcji
}

\begin{abstract}
Energy efficiency is an indicator specifying the amount of saved electric energy thanks to implementation of suitable systems and solutions aimed at reducing the energy consumption in a production plant. Effective use of electric energy or heat energy is intended to reduce the amount of energy required to manufacture products and provide services. Decreased demand for electric energy in the production plant by only a few percent's may result in considerable savings which in turn assure increased production profitability. If we reduce the energy consumption, it will translate into reduced pollution generated and emitted to the environment. Thanks to this, the plant may limit its negative impact on the surrounding. The feed industry is known to consume much amount of energy for the purposes of production. This energy is intended for pre-processing of substrates, actual production and preparation of ready product to be taken over by the customer. Farmers use fodders to feed their animals. Quality of fodders (feeds) and their ingredients determine health of farm animals, which has a direct impact on the quality of products we consume, and consequently on our health. An thorough analysis of feed production plants and reduction of their energy consumption should translate into improved effectiveness. Saved energy allows producing high-quality products and using ingredients of higher quality, which in turn may influence competitiveness of prices of ready products.
\end{abstract}

\section{Introduction}

The plants producing animal feed which belong to the group of agricultural and food processing plants form a manufacturing-technical-organizational structure. The structure of these production plants is dependent upon materials being processed and products these materials form. It entails application of various production technologies relevant to particular production facilities. Feed production plants mostly receive electric energy, and only a small percent of plants produces electric energy which is consumed to supply the entire plant, whereas the surplus of generated energy may be sold to other entities.

The issue of optimizing the energy consumption in these production plants has been popular for many years and implemented in certain production facilities. The main reason for optimizing these plants is the need to lower costs of particular energy carriers, which may directly cause the profits of the plant to rise. In addition, if we decrease the energy consumption, we will support the local eco-climate by reducing the emission of atmosphere pollutants, reducing the noise and producing green energy, which may well be resold to local residents.

Energy optimization process in feed production plants may be a multiple-step process and should engage the entire plant, starting from production halls, through technical rooms or storage rooms, ending up with offices.

\section{Description}

Energy efficiency and renewable energy are considered to be two pillars of well-balanced energy policy. Both strategies must be developed simultaneously in order to stabilize and reduce emissions of carbon dioxide and other pollutants.

Efficient energy consumption is essential and results in hindering the rise of the demand for energy so that rising supplies of pure energy may cause serious reductions of the use of fossil fuels.

Many countries acknowledge the fact that energy efficiency brings benefits for national safety because thanks to this we may limit importing energy from abroad and may hinder the pace of using the domestic sources of energy.

Energy efficiency stands for the amount of saved energy established by means of measuring or estimating the consumption before implementing the means intended to improve the energy efficiency and after implementation, with simultaneous assurance of normalization of external conditions affecting the consumption of energy (Resolution of the EU Commission no. 651/2014 of 17 June 2014 approving certain types of aid in accordance with the internal market pursuant to the art. 107 and 108 of the Treaty (CELEX: 32014R0651)

Effective use of energy is aimed at reducing the amount of energy required to provide products and services. When it comes to feed production plants, it refers to various

\footnotetext{
a Corresponding author: gembicki.jacek@gmail.com
} 
fodders which can be divided into fodders of plant origin, animal origin or mineral feed.

There are many reasons encouraging us to improve energy efficiency. If we limit the energy consumption, we reduce operation costs and consumers may increase savings, provided that energy savings exceed additional expenses related to implementing energy-efficient technologies.

For example, the building thermal insulation assures the use of reduced amount of energy for the purpose of heating and cooling in order to reach and keep the comfortable temperature. The use of fluorescent lamps or skylights reduces the amount of energy but assures as strong illumination as traditional bulbs provide. The improvement of energy efficiency is frequently feasible thanks to more efficient technologies or production processes.

There are many reasons convincing us to improve energy efficiency. Limited use of energy results in reduced operation costs and may lead to savings in the production plant on condition that the energy-related savings exceed additional costs related to implementing energy-efficient technologies. Additionally, it serves to limit the emission of greenhouse gases and other pollutants, and in effect brings other benefits.

The figure 1 shows the impact of the feed production plant on the local agro-ecosystem. It includes products manufactured by the plant, as well as the influence on the neighbourhood through emission of waste water, noise and carbon dioxide.

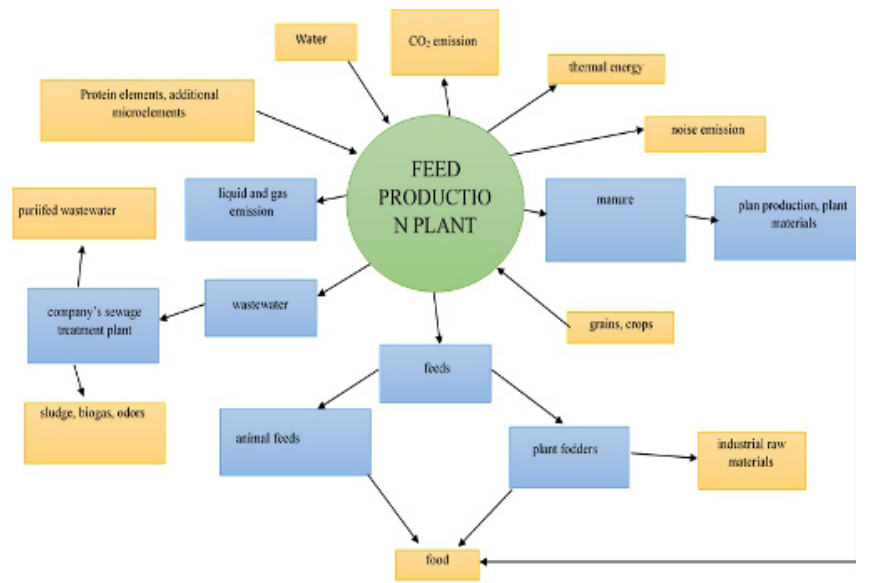

Figure 1. Feed production plant in Agro-ecosystem (prepared by the author)

\section{Literature review}

It has been proved that energy efficiency is a costeffective economy building strategy and does not necessarily require increased energy consumption. Modern and energy-efficient equipment consumes a way less energy than other old-type devices. Advanced boilers and furnaces may operate at high temperatures but consume less fuel. They are more efficient and generate less substances which are harmful to the environment. Electric motors usually operate at the regular speed, but drives of variable speed allow setting the required velocity [1]. Thanks to this, it is possible to save from 3 to $60 \%$ of energy, depending how the engine is used. Engine elements made of superconductive material may also reduce energy losses. Similar effects assures voltage optimization. In the feed industry (but not only) are used many pumps and compressors of various shapes, sizes with a wide range of intended uses. Their efficiency depends on numerous factors, but it can be improved by implementing enhanced inspection of processes and improved maintenance [2]. Compressors are widely used to provide compressed air which is then applied on production lines to transport substrates or ready products. Feed production plants generate steam water and electricity for further own use [3]. When electric energy is generated, the heat, being a side effect of the process, may be collected and used to generate steam, to heat areas, or for other industrial purposes. The conventional generation of electric energy is efficient in ca. 30\%, whereas a simultaneous generation of heat and energy (also referred to as cogeneration) processes up to $90 \%$ of fuel into usable energy [4].

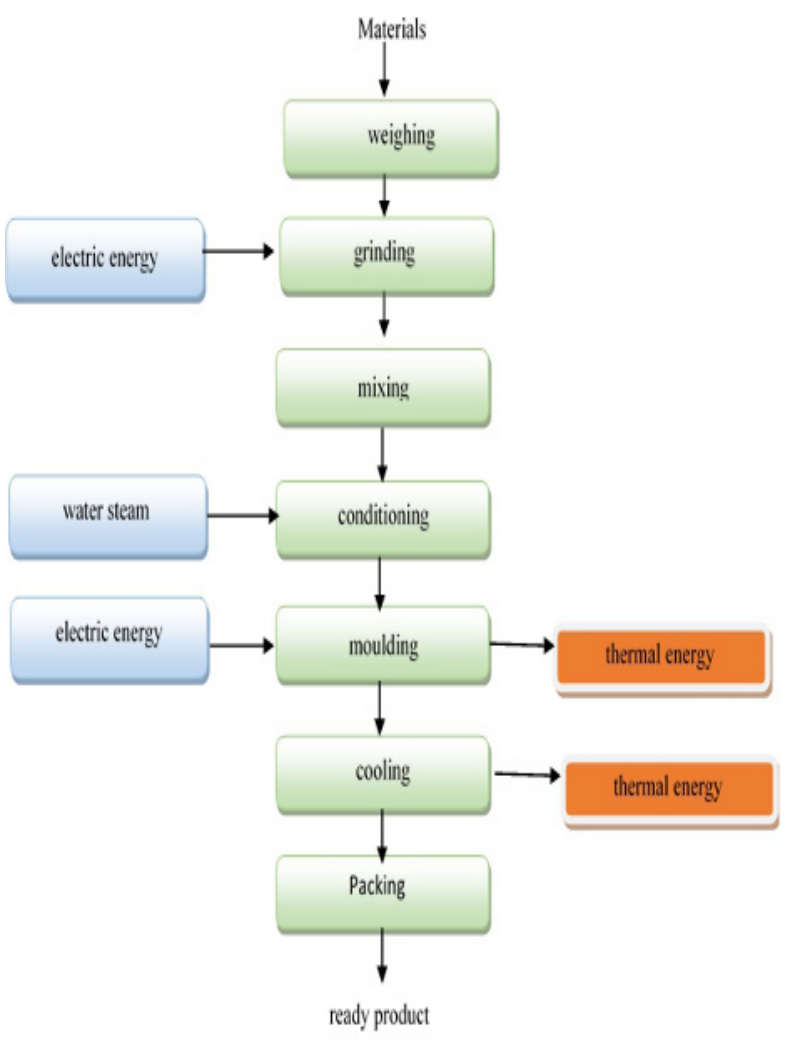

Figure 2. Energy-material flows in the feed production plant (prepared by the author)

The figure 2 shows the example of material flow in the feed production plant. A typical manufacturing process is showed there, starting from supply of substrates used to manufacture a fodder/feed, through particular processes related to the substrates, and ending up with ready product in the form of animal feed [5].

The feed industry uses large amounts of energy to supply various manufacturing processes. Many of these processes require large amounts of heat and mechanical energy which derive from natural gas, oil and electricity. Since manufacturing processes are so diverse, it is impossible to describe all available methods of assuring energy efficiency in the feed industry. A crucial role is played by specific technologies and 
mechanisms implemented in production plants [6]. Nevertheless, we may distinguish an array of processes and energy-related services which can be put into use in feed production plants.

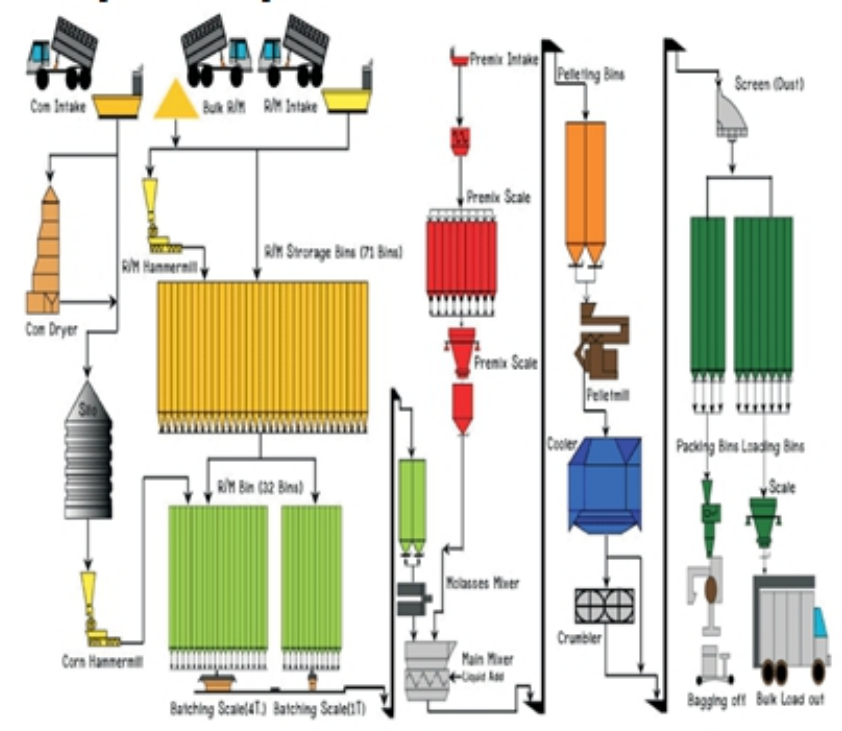

Figure 3. Feed processing system (http://www.scielo.br) Energy forms and carriers:

- Energy in the form of heat (heating, thermal sterilization, evaporation),

- Energy of compressed air (pneumatic transport, packing),

- $\quad$ Electric energy used for motor drives,

- Mechanical energy (grinding, mixing, cleaning, transporting, separating, dosing).

The energy-manufacturing system of agricultural and food processing plants is a separate and internally arranged system of elements with a structure assuring specific production purposes. To examine this sort of system, it is necessary to get familiar with the manufacturing processes in a given plant and to see and measure places which energy is used in. Such assessment of energy management in the plant should provide information on energy carriers wear, method of use and tips on how to improve it. The knowledge of the energy carriers wear may be used in many ways, either to implement new solutions or modernize existing ones in order to make them more effective. The question arises of whether the existing testing methods, used to specify chances for reduction of energy carriers wear and specification of improvement actions, are sufficient and whether have been used in a proper way. Aside from basic features, the method should be justified from the scientific and technical point of view [7].

We distinguish two basic methods. The top-down method is concerned with the top-down approach and limits itself to analyzing input and output parameters. In this method processes occurring inside the system in question are not considered. The main advantages of this method is among others low costs, simplicity, easy monitoring and forecasting of energy consumption, as well as considerable flexibility and versatility. In turn, the bottom-up method focuses on a precise and in-depth analysis of the production process, thanks to which we can improve energy efficiency. Plus, it is possible to develop a detailed system model by means of which we can carry out a precise simulation showing weak links of the system and their improvement [8]. In order to indicate possible methods of assessing the energy management, in the first place it is necessary to isolate areas and then conduct their analysis to draw conclusion influencing the decisions related to improvement of energy efficiency in the production plant [9].

How to save energy:

- Suitable (full) use of electric motors in terms of power

- Increased use of production machines during continuous operation

- Reasonable use of lighting installation

- Use of thermal insulation of receivers and buildings

- Reduced number of energy conversions (e.g. replacing water steam with hot water),

- Heat recovery (recirculation)

- Shortening the length of transmission lines of heat carriers.

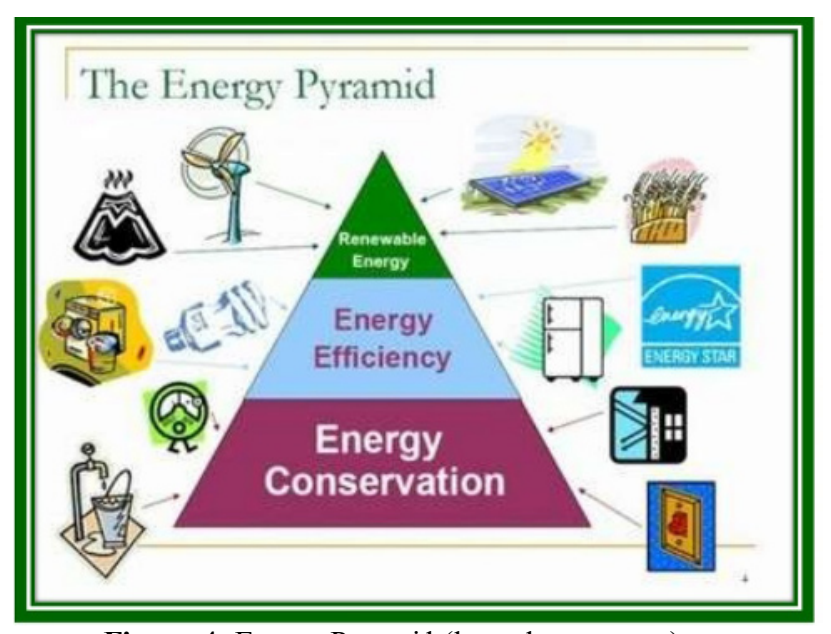

Figure 4. Energy Pyramid (legendpower.com)

\section{Summary}

To have an insight into energy consumption in animal feed production plants, it is necessary to choose relevant testing methods and specify which of them are the most effective, and provide credible and reliable results. Thanks to a suitable testing method, we are able to estimate the energy consumption and if it is too high, we may try to implement relevant processes in order to reduce the aforementioned consumption. If the process turns out to be effective, we may increase profits of the production plant, and thus become more competitive on the feed market. When discussing the issue of energy consumption, it is not only about the use of electric energy but also thermal energy. If we lower the demand for thermal energy or if we use it in a better way, we will be able to reduce the emission of greenhouse gases to the environment, and for this reason the production plant will have lower influence on the local eco-climate.

To sum up, if we test the energy consumption and attempt to reduce it, the feed production plant and its surrounding will benefit from it. We should remember however that it is of paramount importance to get familiar with the entire manufacturing process and the plant structure, as well as estimate potential improvement costs and forecasted profits in order to make sure 
the improvement pays off. Thanks to such balance, we will learn if the modernization is profitable or not.

\section{References}

1. Z. Narski, Przemysł Spożywczy, 8, (1983)

2. N. Marks, Z. Sobol, Inżynieria Rolnicza, 3, 78 (2006)

3. B. Dróżdż, Annals of Warsaw University of Life Sciences, 56

4. B. Dróżdż, Metodyczne i utylitarne aspekty analizy energochłonności przetwórstwa rolno-spożywczego, p.20-25 (2013)

5. B. Dróżdż, MOTROL Motoryzacja i Energetyka Rolnictwa, Modelowanie zużycia energii w przemyśle rolno-spożywczym, p. 349-356 (2010)

6. R. Akinoso, K. Olatoye, International Food Research Journal Energy, 20 (2013)

7. K. Brodowicz, M. Markowski, Gospodarka Paliwami i Energią, 9 (1997)

8. J. Budny, Problemy gospodarki energią w przemyśle mleczarskim, Definicja i ogólna metodyka wyznaczania wskaźnika zużycia energii w przemyśle mleczarskim, p.25-26 (1988)

9. J. Budny, J. Turowski, Inżynieria przetwórstwa spożywczego, 4, 4 (2012)

10. J. Grochowicz, K. Zawiślak, Inżynieria Przetwórstwa Spożywczego, 2, 2 (2012) 